\title{
Morphoanatomy of the flower of Syagrus inajai (SPRUCE) Becc. (Arecaceae- Arecoideae- Attaleinae), Amazon
}

\author{
Genovese-Marcomini, PR. ${ }^{a}{ }^{*}$, Mendonça, $M S^{b}{ }^{b}$ and Carmello-Guerreiro, $S M^{c}$ \\ anstituto Nacional de Pesquisas da Amazônia - INPA, Av. André Araújo 2936, CEP 69.060-001, Manaus, AM, Brazil \\ ${ }^{b}$ Departamento de Ciências Fundamentais Agrícola, Faculdade de Ciências Agrárias, Universidade Federal do \\ Amazonas, CEP 69037-000, Manaus, AM, Brazil \\ ${ }^{c}$ Departamento de Biologia Vegetal, Instituto de Biologia, Universidade Estadual de Campinas - UNICAMP, CP 6.109, \\ CEP 13.083-970, Campinas, SP, Brazil \\ *e-mail: polianaroversibe@yahoo.com.br
}

Received June 5, 2012 - Accepted August 8, 2012 - Distributed August 31, 2013

(With 7 figures)

\begin{abstract}
The occurrence of Syagrus inajai (Spruce) Becc., popularly known as pupunha palm, among other names, has been registered in the Guianas and in the North of Brazil in areas of terra firme (non-flooding) and gallery forests. In order to characterize the inflorescence and further knowledge of this family, a morphoanatomical study was carried out of the palm S. inajai in a green area of the Campus of the Federal University of Amazonas - UFAM, Manaus, Amazonas. The inflorescences are branched to one order, pedunculate, and interfoliar, measuring $62-82 \mathrm{~cm}$ in length, with woody bracts with longitudinal grooves on the external surface, and flowers in triads. The number of flowers to each inflorescence varies from 5,904 to 17,316 for staminate flowers, and from 180 to 3,528 for pistillate flowers. Staminate flowers with six anthers and one vascular bundle each; three-lobed pistillodium, vascularized pistillodium. Its pistillate flowers have six staminodia joined to form a circle, syncarpic, tricarpellary, trilocular gynoecium, one ovule to each locule, synascidiate in the ovary, and plicated above. Tripartite stigma, apical and sessile, with epidermis composed of elongated papillary cells, pattern of epidermis that is maintained throughout the stylar canal. Bitegmented, anatrope, pachychalazal ovule.
\end{abstract}

Keywords: Syagrus, anatomy, flowers of Palmae, Cocoseae tribe, pupunharana.

\section{Morfoanatomia floral de Syagrus inajai (Spruce) Becc. (Arecaceae- Arecoideae- Attaleinae), Amazônia}

\section{Resumo}

Syagrus inajai (Spruce) Becc., popularmente conhecida como pupunha-brava entre outras denominações, teve sua ocorrência registrada para Guianas e no norte do Brasil em áreas de floresta de terra firme e floresta de galeria. Com o intuito de caracterizar a inflorescência ampliando o conhecimento a respeito da família foi realizado o estudo morfoanatômico da palmeira S. inajai, em área verde do Campus da Universidade Federal do Amazonas - UFAM, Manaus, Amazonas. A inflorescência é ramificada em primeira ordem, pedunculada, interfoliar com $62-82 \mathrm{~cm}$ de comprimento, bráctea lenhosa com fissuras longitudinais na superfície externa e flores em tríades. O número de flores por inflorescência varia entre 5.904 - 17.316 para flores estaminadas e 180 - 3.528 para as flores pistiladas. Flores estaminadas com seis anteras e um feixe vascular cada; pistilódio trífido e vascularizado. Flores pistiladas com seis estaminódios unidos formando um círculo. Gineceu sincárpico, tricarpelar, trilocular, um óvulo por lóculo, sinascidiado no ovário e plicado acima. Estigma tripartido, apical e séssil, com epiderme composta por células papilosas alongadas, padrão de epiderme que se mantem por todo canal estilar. Óvulo é anátropo, paquicalazal e bitegumentado.

Palavras- chave: Syagrus, anatomy, flores de Palmae, tribo Cocoseae, pupunharana.

\section{Introduction}

The genus Syagrus is composed of 31 species (Dransfield et al., 2008), distributed in South America, western Columbia, French Guiana, southern Uruguay, and northern Argentina. Eleven of the species are endemic to the Antilles, and Brazil, the country with the highest number of species (Henderson and Scariot, 1993; Henderson, 1995; Henderson et al., 1995). They grow predominantly in cerrado and caatinga vegetations, and soils with rocky outcrops (Henderson et al., 1995; Dransfield et al., 2008), but the occurrence of six species has also been reported for the Amazonian Biome, namely: 
Syagrus cocoides Mart., Syagrus inajai (Spruce) Becc., Syagrus orinocensis (Spruce) Burret., Syagrus sancona (Kunth) H. Karst., Syagrus smithii (H.E.Moore) Glassman, and Syagrus stratincola Wess. Boer (Henderson, 1995, Henderson et al., 1995).

$S$. inajai is a palm that is commonly found in gallery and terra firme forest, with many individuals in open areas where there are signs of anthropization. It is a monoic species with eye-catching inflorescences, and up to 35 rachillae (Henderson and Scariot, 1993; Henderson et al., 1995).

Syagrus like the other genera of the Cocoseae tribe, is characterized by inflorescences with large peduncular, persistent bracts, and fruits with a hard endocarp and three pores (Dransfield et al., 2008), reproductive characters that are used to distinguish taxon.

In the Arecaceae family as a whole, the evolution of floral characters has been observed, including progression from bisexual to unisexual flowers, and from monoic to dioic species (Moore and Uhl, 1982; Daher et al., 2010). Morphoanatomical study of the flower is of considerable value for delimiting monophyletic groups, whether alone or in combination, and provides a better understanding of the mechanisms of speciation and coevolution of the phylogenetic relations (Moore and Uhl, 1982; Askgaard et al., 2008). It also enables observation of structures linked to pollination and fertilization, as well as providing data to support works in Ecology and Physiology and other related areas.

With just a few exceptions, palms are propagated by seeds, which present slow, unequal germination, influenced by various factors such as state of maturation, presence or absence of a pericarpium, time between harvesting and planting, physical dormancy, environmental temperature, and substrate (Meerow, 1991; Salm, 2005; Pivetta et al., 2008). Given that the seed is the main means of propagation and establishment of palm species, it is essential to understand the morphology and anatomy of the reproductive organs of the plant. The morphoanatomical characterization of a certain flower enables us to observe the tissues that comprise it, and that comprise the formation of the fruit and the seed.

Therefore, morphoanatomical characterization of the flower of $S$. inajai will lead to a better understanding of the processes of formation of the fruit and seed, providing information that will serve as the basis for ontogenetic and ecological studies, and studies of the Floral Biology and Taxonomy.

\section{Material and Methods}

The botanical material was collected in 2009 and 2010 in a green area of the Campus of the Federal University of Amazonas - UFAM, Manaus, Amazonas, Brazil, in a region of baixio (flat valley) forest, close to coordinates $03^{\circ} 05^{\prime} 45,84^{\prime \prime} \mathrm{S}$ and $59^{\circ} 58^{\prime} 43,69^{\prime \prime}$, a climate characterized as being of the Afi type (Köppen, 1931). The material was analyzed at the Agroforestry Botanical Laboratory - LABAF, of the same University. For the morphological and anatomical description, ten adult individuals of $S$. inajai were selected, from which the characterized inflorescences were removed for field and laboratory observation, according to Tomlinson (1990) and Dransfield et al. (2008).

The flowers were measured (length and width) and quantified, estimating the average number per inflorescence and per rachilla and their positions on the rachis. Five basal, five middle and five apical rachillae were counted. Subsequently, Tukey's test was applied with alpha of $5 \%$ to calculate the level of significance.

For the anatomical study, the material collected (rachillae with staminate and pistillate flowers) was fixed in FAA 70\% (Kraus and Arduin, 1997). The samples were dehydrated in ethyl series (70\%- $95 \%)$, embedded in 2-hydroxyethyl-methacrylate (Historesin $\AA$ Leica, prepared according to the manufacturer's instructions), sectioned at thicknesses of 4 to $7 \mu \mathrm{m}$ in a rotary microtome, and stained with $0.5 \%$ toluidine blue in citrate buffer, $\mathrm{pH} 4.0$ (O'Brien et al., 1964), and the slides were mounted in water. The semi-permanent slides were prepared from sections cut freehand using razor blades, cleared, stained with safranin and astra blue in aqueous solution (Bukatsch 1972) and mounted in glycerinated gelatin (Dop and Gautié, 1928).

For the registration of the material in a Scanning Electron Microscope (SEM), the botanical material was fixed in BNF (Buffered Neutral Formalin, Lillie, 1965) solution, dehydrated in ethyl series, and dried by the critical point method with $\mathrm{CO}_{2}$ on a Balzers model CPD 030 . The samples were collected in a metal support, covered with gold (Balzers SCD 050) and observed under a JEOL JSM 5800LV (10 kV) Scanning Electron Microscope, at the Institute of Biology/Unicamp.

Histochemical tests were performed, seeking to observe some ergastric substances, using the following dyes and reagents: Lugol to detect starch (Jensen, 1962), Ruthenium Red to identify various polysaccharides and pectins (Johansen, 1940); Xilidine Ponceau (O' Brien and McCully, 1981) to detect protein reserves; Sudan IV (Brundett et al., 1991) to detect lipophilic substances, and Iron Chloride III to determine the occurrence of general phenolic compounds (Johansen, 1940).

The results were documented in a Zeiss photo microscope, Primo Star model, with Canon photographic camera (Power Shot A650 IS). Indian ink drawings were made of the general morphological appearance and coloration of the inflorescence, characterized according to the table of Kornerup and Wanscher (1961).

\section{Results}

The individuals of $S$. inajai (Figure 1) flower all year round, with one to three inflorescences per individual. But flowering is higher from February to July, outside the dry period.

It is a monoic palm, with staminate and pistillate flowers in the same inflorescence. However, we ob- 


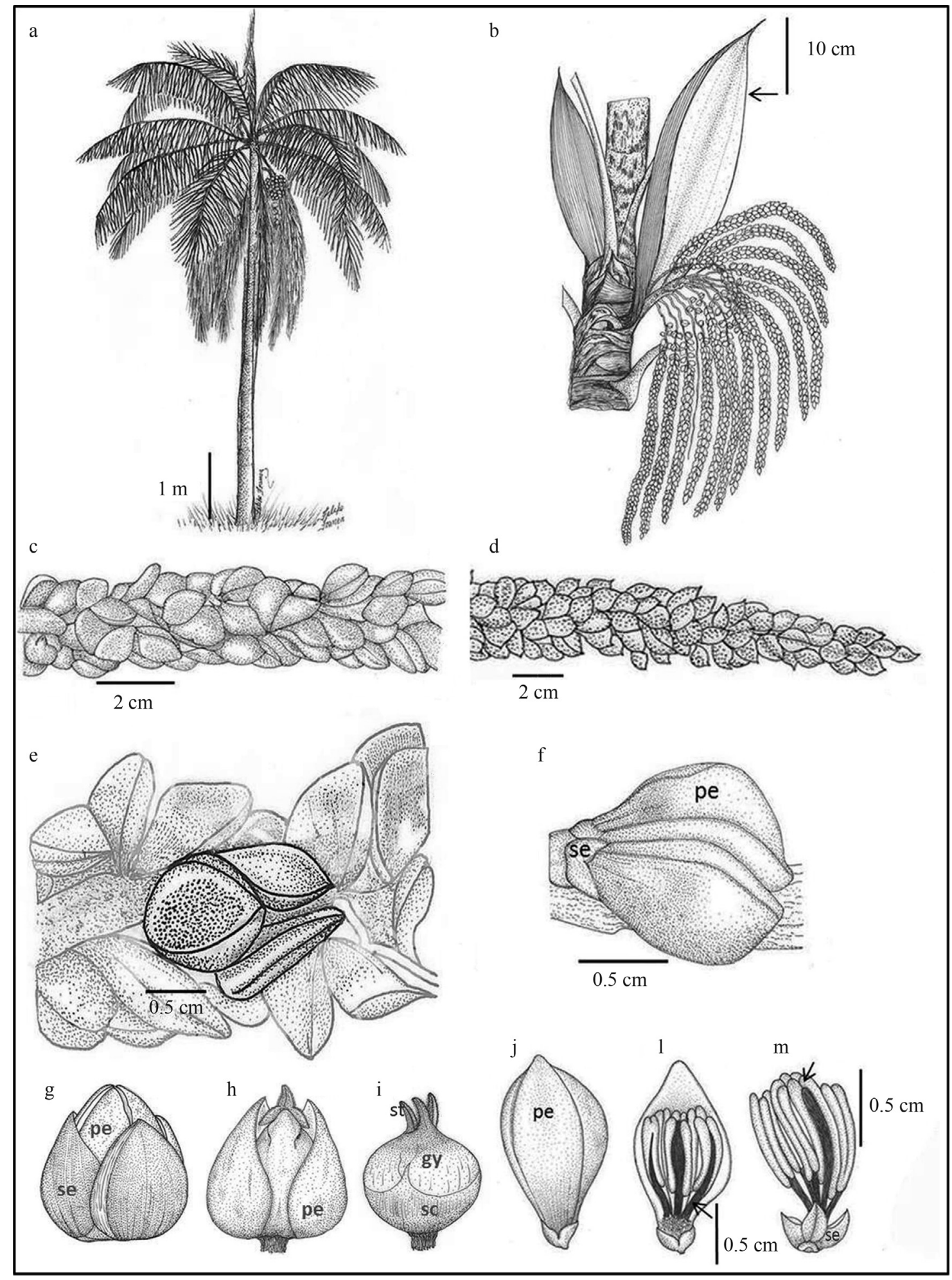

Figure 1 - Morphological aspects of S. inajai. a) General appearance of the plant; b) Inflorescence, peduncular bract (arrow); c) Base of the rachilla; d) Apex of the rachis; e) Flowers in triads; f) Staminate flowers in dyads; g) Pistillate flower; h) Pistillate flower without sepal; i) Gynoecium, detail of staminoid circle and stigma open; j) Staminate flower; 1) Detail of flower, filament (arrow); and m) Arrangement of the anthers, (arrow). (gy: gynoecium, pe: petal, sc: staminoid circle, se: sepal, st: stigma). 
served ten entirely male inflorescences, a finding not previously reported for the species.

The peduncular bract is woody, 57 to $88 \mathrm{~cm}$ in length. It surrounds the inflorescence during part of its development, a period lasting for 50 to 60 days after its emergence (Figure 1a-b). The external surface is waxy bronze-brown, with lanugo at the base and longitudinal grooves; the internal surface is glabrous and golden, but after opening, it oxidizes, changing in color.

The inflorescence is interfoliar, pedunculate, branched to one order, and pale yellow, with a strong, sweet odor, $62-82 \mathrm{~cm}$ in length (Figure 1a-b). The species is protandric. The staminate flowers open simultaneously with the peduncular bract, remaining in flower for one to two days after anthesis, thereby avoiding self-pollination. The peduncle is pale orange, cylindrical, lanuginous, and grows to $18-25 \mathrm{~cm}$ in length. The rachis is cream-colored and lanuginous, measuring $17-28 \mathrm{~cm}$ in length. The rachilla are cream-colored, with significant variations in length from the base to the apex (Table 1), ranging from 18 to 36 in number.

The flowers are arranged in cincinni forming base triads up to the middle of the rachilla. The pistillate flower is flanked by staminate flowers (Figure 1c, e), On the apex of the rachilla the staminate flowers are arranged in dyads or acervulae (Figure 1d, f).

Considering the minimum and maximum number of staminate and pistillate flowers per rachilla, and the minimum and maximum number of rachilla per inflorescence, it is inferred that the number of flowers per inflorescence varies between 5,904-17,316 and 180-3,528, respectively (Table 3).

\subsection{Staminate flower}

The staminate flowers have a uniform cream-yellow coloration or wine-colored base. They are elliptical, irregular, asymmetrical in shape, and sessile. The sepals are connate at the base, with three triangular apical lobes, acuminate apex, indented edges, glabrous (Figures 1f, $\mathrm{j}-\mathrm{m}$ and $2 \mathrm{a})$. There are three valvar, free, lanceolate,
Table 1 - Measurements for length of the rachillae inserted in the base, middle and apex of the rachis of the inflorescence, mean (Mean), maximum (Max.) and minimum (Min.), of S. inajai (Spruce) Becc.

\begin{tabular}{lccc}
\hline \multirow{2}{*}{$\begin{array}{l}\text { Position of the } \\
\text { rachillae on the rachis }\end{array}$} & \multicolumn{3}{c}{ Length of the rachilla (cm) } \\
\cline { 2 - 4 } & Mean & Max & Min \\
\hline Base & $46.2^{\mathrm{a}}$ & 57 & 34.5 \\
Middle & $43.1^{\mathrm{ab}}$ & 53 & 33.8 \\
Apex & $38.6^{\mathrm{b}}$ & 47.1 & 31.5 \\
\hline
\end{tabular}

Letters the same for mean in the same column represent non-significant differences, Tukey's test, $\alpha=5 \%$.

asymmetrical petals with non-indented margin, thick apex and acuminate (Figure 1f, j).

There are six free stamen, with wider filaments at the base; the anthers have asymmetric tips and are dorsifixed, with longitudinal dehiscence, and introrse (Figure 11-m). Short, three-lobed, central pistillodium (Figure $2 b)$.

The flowers are 6.81 to $11.44 \mathrm{~mm}$ in length and 2.41 to $5.24 \mathrm{~mm}$ in width, and are located in the apical rachillae of significantly shorter length (Table 2). The number of flowers per rachilla was between 328 and 481 (Table 3).

The sepal and petal have a thickened cuticle in the epidermis on the adaxial side, in the external periclinal and anticlinal walls (Figure 3c) and on the abaxial surface, only in the external periclinal wall (Figure 3d). They are richly vascularized, with vascular bundles surrounded totally in the sepals and partially in the petals by a sclerenchyma sheath (Figure $3 \mathrm{a}-\mathrm{b}$ respectively). In the petals, the sclerenchyma cells form a calotte on the adaxial side of the vascular bundle, arranged throughout the extension of the mesophyll (Figure 3b).

Each stamen contains one vascular bundle. The anther is formed by a unistratified epidermis, and the endothecium is composed of cells, with elongated periclinal

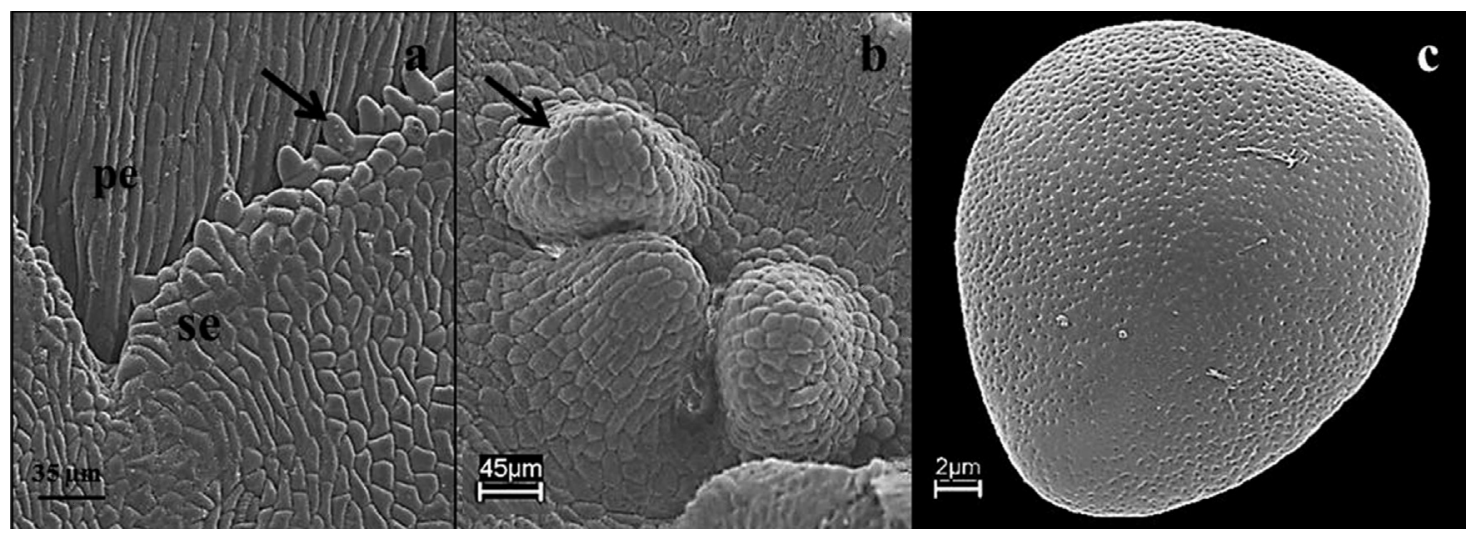

Figure 2 - Scanning electron micrograph of the staminate flowers of S. inajai. a) Indented margin of the sepal, arrow; b) Pistillodium (arrow); and c) Pollen grain. (pe: petal, se: sepal). 


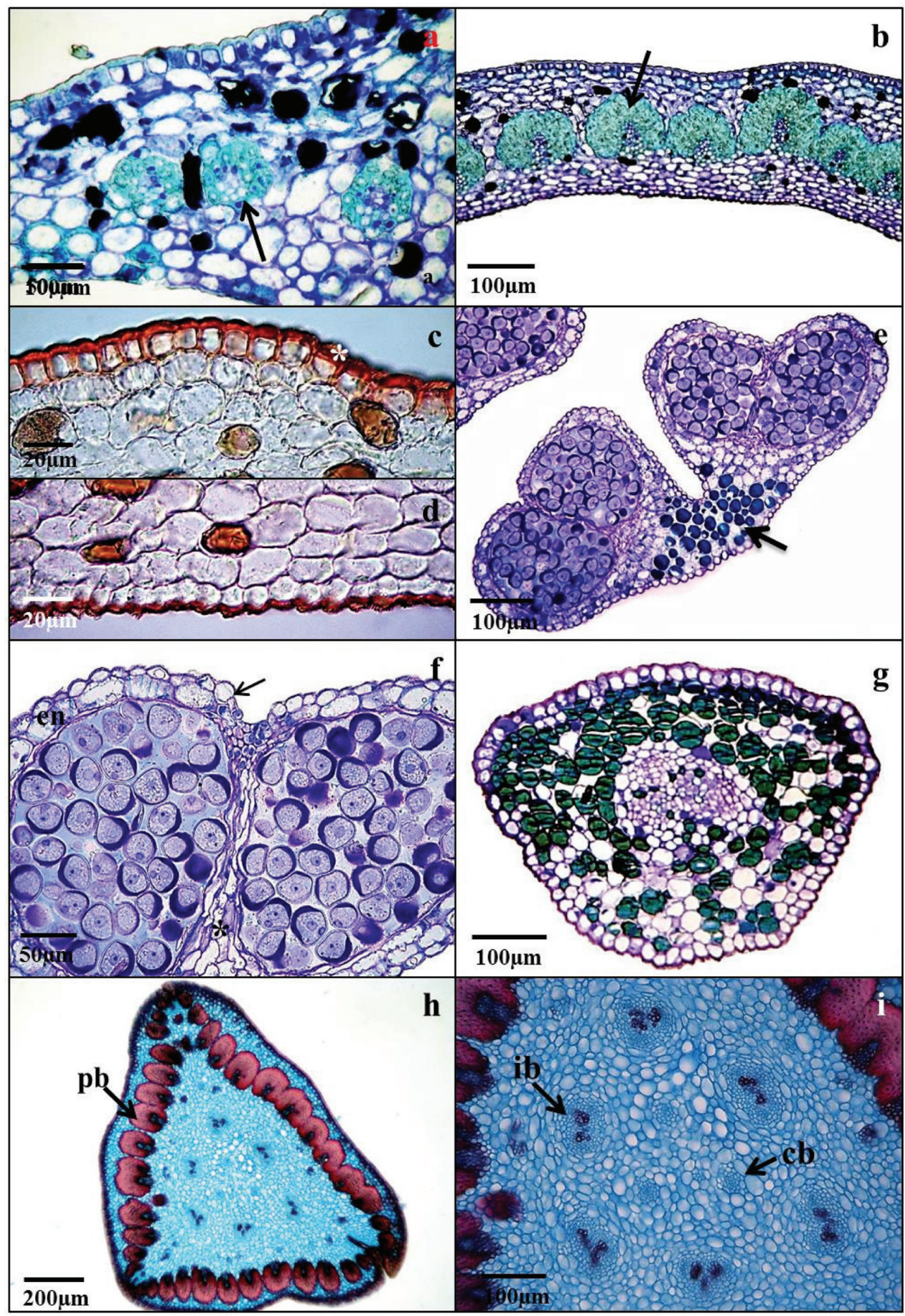

Figure 3 - Photomicrograph of the staminate flower of $S$. inajai. a-i) Cross-section; a) Sepal, vascular bundle (arrow); b) Petal, vascular bundle (arrow); c) Adaxial surface of the sepal, cuticle (asterisk); d) Abaxial surface of the petal; e) Anther, connective (arrow); f) Detail of the theca, epidermis (arrow), stoma cells (asterisk); g) Filament; h) Receptaculum; and i) Region of the pistillodium. (cb: central vascular bundles, en: endothecium, ib: intermediary vascular bundles, pb: peripheral vascular bundles). 


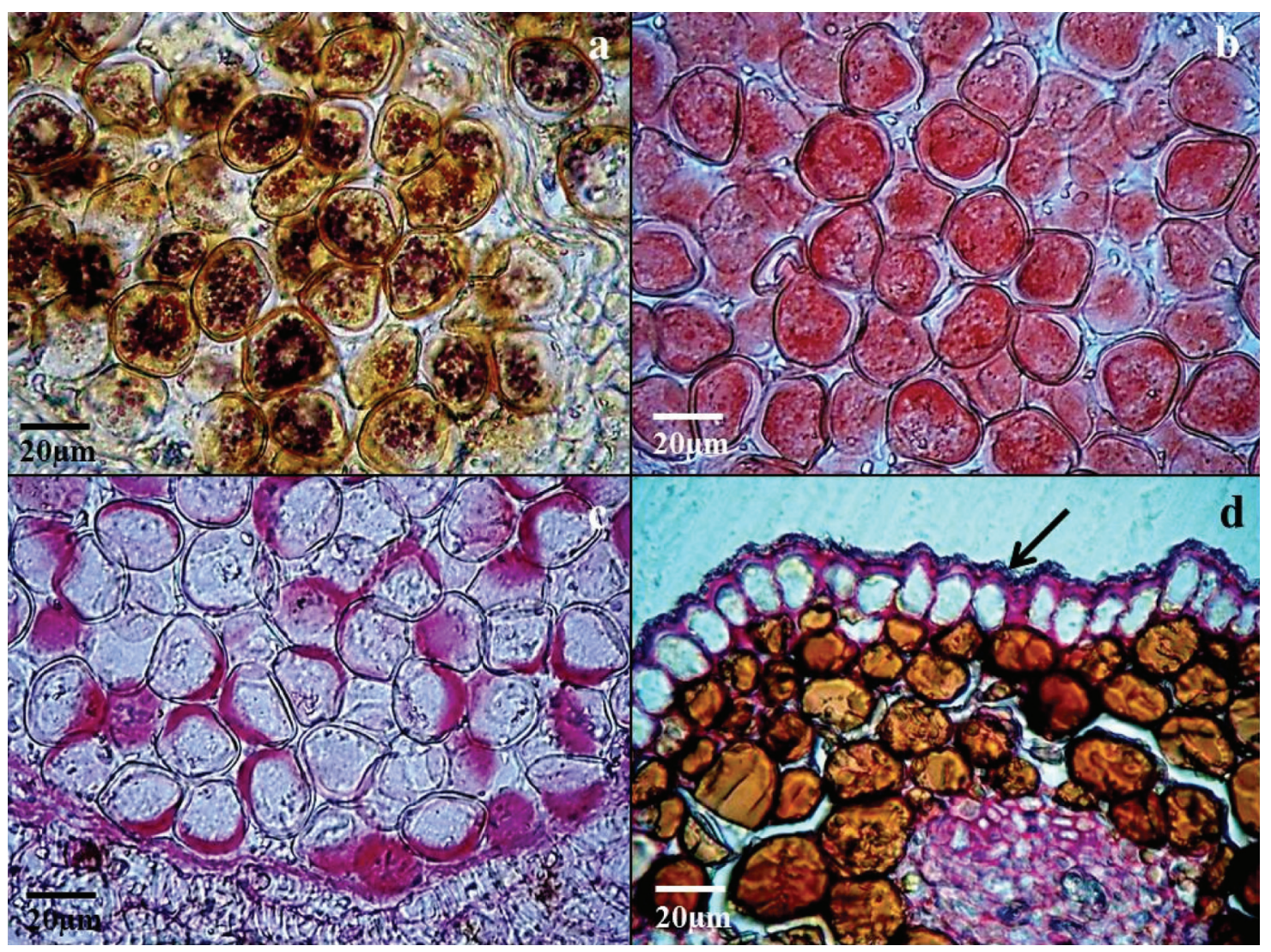

Figure 4 - Photomicrograph with the reaction of the histochemical tests applied to the staminate flower of $S$. inajai. a) Pollen grain with starch reserve, black; b) Test for protein, protein bodies in red; c) Pectic nature of the wall of the microspore gain; and d) Pectic nature of the cell wall in the epidermis of the filament (arrow).

cells and irregular wall thickness (Figure 3e-f). Between each theca there are two to four layers of thin stroma cells, which break down in the anthesis, forming the longitudinal stomium, an opening through which pollen grains are released (Figure $3 \mathrm{f}$ ). The pollen grain has a reticulate surface and cell wall of pectic nature (Figures $2 \mathrm{c}$, 4c), and contains starch and protein (Figure 4a-b, respectively). The tissue of the connective is endothecium-like (Figure 3e). The filament has an epidermis with thickened external periclinal and anticlinal walls and a vascular bundle surrounded by idioblasts with phenolic compounds (Figures 3g, 4d). The pistilodium (Figure 2b) has three vascular bundles (Figure 3i). In cross-section, vascular bundles arranged in three levels can be seen in the receptaculum: approximately 46 peripheral vascular bundles with sclerenchyma sheath, surrounding the sepals and petals (Figure $3 \mathrm{~h}$ ); three central vascular bundles that will form the pistilodium, and six intermediary vascular bundles surrounding the anthers (Figure 3i).

\subsection{Pistillate flower}

The pistillate flowers are cream in color, pyramidal, asymmetrical and trimerous, 4.92 to $7.24 \mathrm{~mm}$ in length and 4.44 to $6.09 \mathrm{~mm}$ in width (Table 2). The sepals are overlapping, free, pyramidal with thin margins, tomen- tose, and tomentose-floccose in the depressions (Figures $1 \mathrm{~g}$ and $5 \mathrm{a})$. The petals are overlapping, free, pyramidal with irregular edges, rounded bases, acute apex, thick, floccose-tomentose in the depressions, and longer than the sepals (Figures 1g-h and 5a). The stigma is tripartite, regular and apical (Figures 1h-i and 5b). The number of pistillate flowers per rachilla is 10 to 98 . However, in terms the average number of flowers per rachilla in relation to their position on the rachis, there is no significant difference (Table 3). The ovary is superior, syncarpic, tricarpellary and trilocular, with one ovule to each locule and basal lateral placentation (Figure 6a). The staminods are connate a circle, and ring membranous, with six vestigial stamens (Figure 1i).

The sepal and petal present an epidermis covered by cuticle on both sides, thicker on the adaxial side; the mesophyll consists of vascular bundles surrounded by a sclerenchyma sheath, and present groups of sclerenchyma cells close to the abaxial surface, in high quantities in the sepals (Figure 7a-b).

The staminoid circle has a uniseriate epidermis, thick cuticle on the external periclincal wall, parenchyma mesophyll with a high number of idioblasts throughout its extension, and vascular bundles (Figure 7c). 


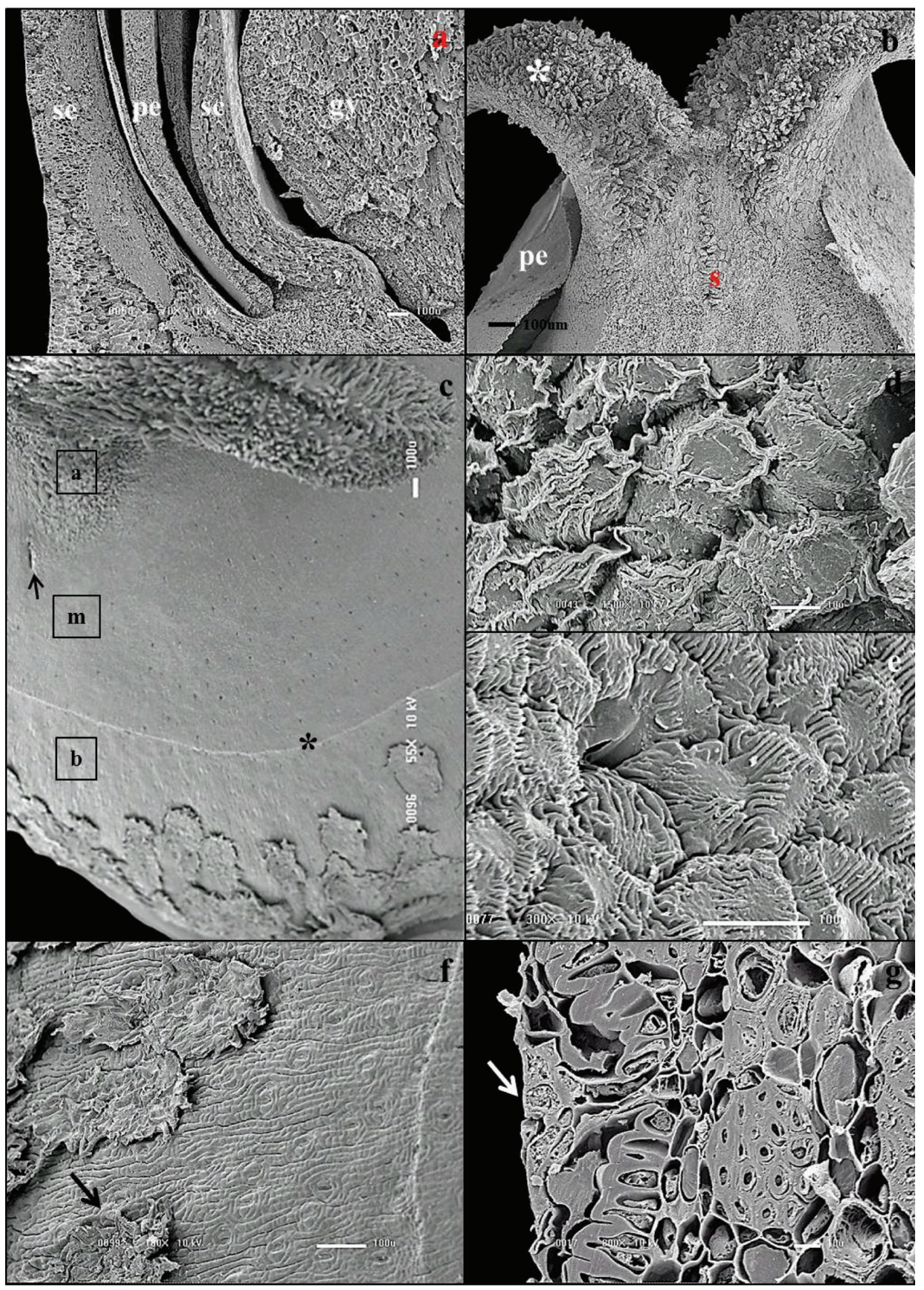

Figure 5 - Scanning electron micrograph of the pistillate flower of S. inajai. a-b) Longitudinal section; a) Floral parts; b) Detail of the stigma (asterisk); c) Regions of the gynoecium, apical (a), middle (m) and basal (b), depression delimiting the stamen ring (asterisk), opening of the septal canal (arrow); d) Cuticle, apical region; e) Middle epidermis region; f) Squamiform trichome (arrow); and g) Longitudinal section of the squamiform trichome (arrow). (gy: gynoecium, pe: petal, s: stylar canal, sc: staminoid circle se: sepal). 


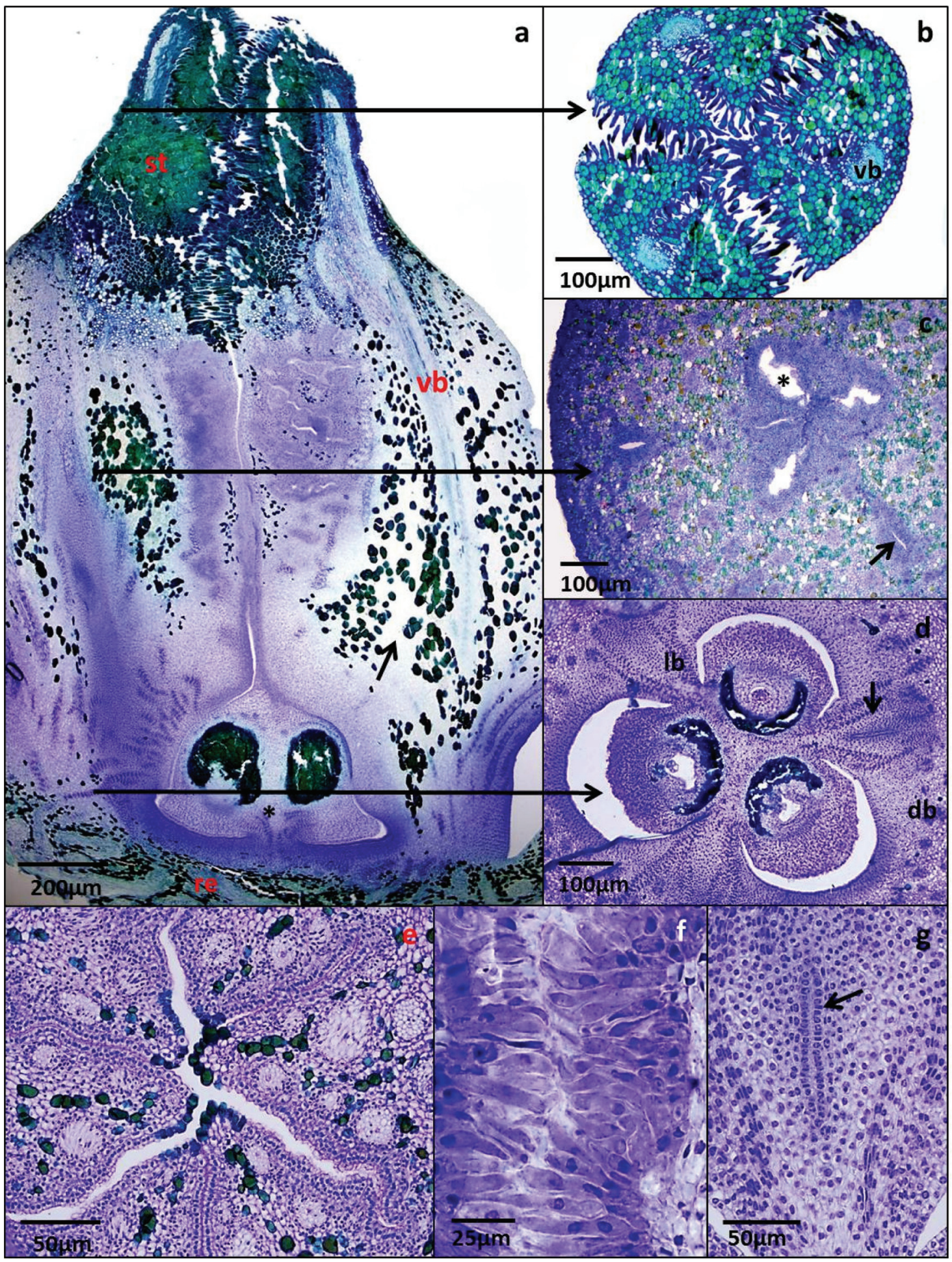

Figure 6 - Photomicrograph of the pistillate flower of $S$. inajai. a) Longitudinal section of the gynoecium, ovules (asterisk), idioblasts (arrow); b-e) Cross-section of the gynoecium; b) Stigma, vascular bundle; c) Region of the stylar canal (asterisk), septa (arrow); d) Ovary, showing the locules, septum (arrow); e) Stylar canal; f) Longitudinal section of the epidermis of the stylar canal; and g) Septum with secretory epidermis. (db: dorsal bundle, lb: lateral bundle, re: receptaculum, st: stigma, vb: vascular bundle). 


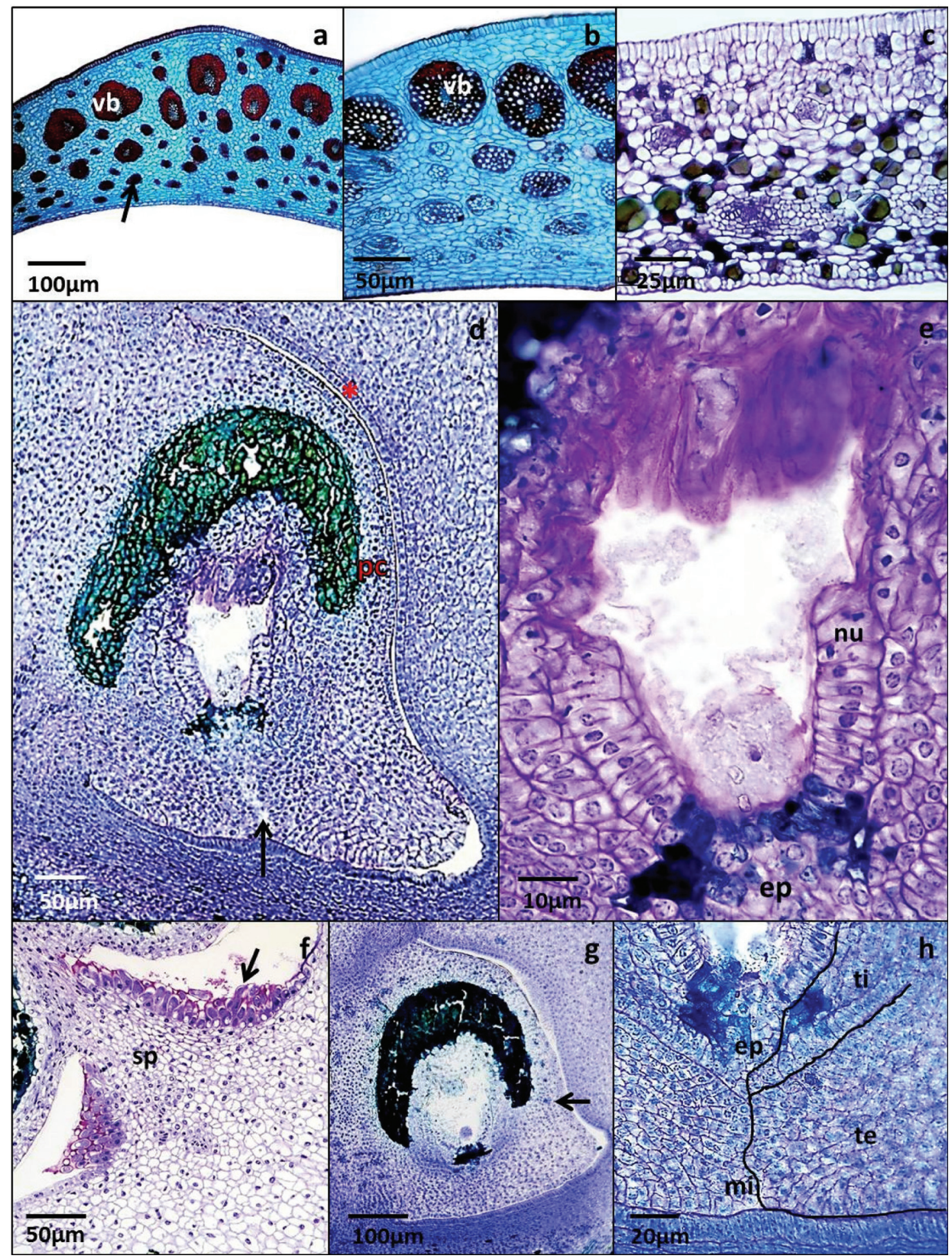

Figure 7 - Photomicrography of the pistillate flower of S. inajai. a-c) Cross-section; d-h) Longitudinal section; a) Sepal; b) Petal; c) Staminodes circle; d) Detail of the ovule, internal epidermis of the ovary (asterisk), micropyle (arrow); e) Embryo sac; f) Obturator (arrow); g) Pachychalaza, vascular bundle (arrow), hypostasis with phenolic compounds; and h) Region of the micropyle. (ep: epistase, mi: micropyle, nu: nucellus, pc: pachychalaza, sp: septum, te: outer tegument, ti: inner tegument, vb: vascular bundle). 
Genovese-Marcomini, PR., Mendonça, MS. and Carmello-Guerreiro, SM.

Table 2 - Number of staminate and pistillate flowers per rachilla, comparing rachillae positioned at the base, middle and apex of the rachis of S. inajai (Spruce) Becc.

\begin{tabular}{lcccccccccc}
\hline & \multicolumn{3}{c}{ Staminate flowers/rachilla } & & \multicolumn{3}{c}{ Pistillate flowers/rachilla } \\
\cline { 2 - 4 } \cline { 9 - 11 } Position & Mean & & Max. & Min. & & Mean & & Max. & Min. \\
\hline Base & 383.9 & ab & 474 & 328 & & 63.9 & A & 98 & 28 \\
Middle & 400.4 & a & 481 & 340 & & 57.7 & A & 80 & 33 \\
Apex & 368.8 & b & 430 & 332 & & 48.7 & A & 91 & 10 \\
\hline
\end{tabular}

Letters the same for mean in the same column represent non-significant differences, Tukey's test, $\alpha=5 \%$.

Table 3 - Measurements for length and width, mean (Mean), maximum (Max.) minimum (Min.) of the pistillate and staminate flowers comparing the rachillae positioned at the base, middle and apex of the rachis of S. inajai (Spruce) Becc.

\begin{tabular}{|c|c|c|c|c|c|c|c|c|}
\hline & \multicolumn{4}{|c|}{ Length (mm) } & \multicolumn{4}{|c|}{ Width (mm) } \\
\hline & Mean & & Max. & Min. & Mean & & Max. & Min \\
\hline \multicolumn{9}{|c|}{ Pistillate flower } \\
\hline Base & 6.29 & $\mathrm{a}$ & 6.96 & 5.68 & 5.31 & $\mathrm{a}$ & 5.87 & 4.65 \\
\hline Middle & 6.15 & $\mathrm{a}$ & 7.03 & 4.92 & 5.27 & $\mathrm{a}$ & 6.09 & 4.44 \\
\hline Apex & 6.31 & $\mathrm{a}$ & 7.24 & 5.17 & 5.18 & $\mathrm{a}$ & 6.05 & 4.5 \\
\hline \multicolumn{9}{|c|}{ Staminate flower } \\
\hline Base & 9.08 & $a b$ & 10.94 & 7.36 & 4.11 & $\mathrm{a}$ & 5.24 & 3.16 \\
\hline Middle & 9.56 & $\mathrm{a}$ & 11.44 & 8.18 & 3.95 & $\mathrm{a}$ & 5.02 & 2.41 \\
\hline Apex & 8.96 & $\mathrm{~b}$ & 10.08 & 6.81 & 4.07 & $\mathrm{a}$ & 5.24 & 3.02 \\
\hline
\end{tabular}

Letters the same for mean in the same column represent non-significant differences, Tukey's test, $\alpha=5 \%$.

The gynoecium has three distinct regions (Figure 5c): an apical region, with the stigma, characterized by epidermal cells with ornamented cuticle; a middle region with a short stylet whose epidermal cells have a high number of stomata and a basal region of the ovary, characterized by the presence of a stamen ring with thin cuticle cells, stomata and multicellular squamiform tricomas (Figure 5d-g).

The ovary is formed by three carpels linked at the base, synascidiate, but above this region the bond is not complete, constituting a single, synplicate stylar canal (Figure 6a-d).

The stigma contains three vascular bundles (Figure 6b). The inner epidermis of the stigma in continuity with the stylar canal, as far as the inner epidermis of the ovary, consists of elongated papillary cells (Figures 5b-c and $6 \mathrm{~b}, \mathrm{f})$. In cross-section, the stylar canal is triradiate, with folds, and smaller invaginations entering the mesophyll, like labyrinths (Figure 6a, c, e).

The septa located between the carpels are formed by the fusion of their margins. However, this fusion is incomplete, forming cavities, one per septum, arranged radially from the base of the ovary to the base of the stigma, with a secretory epidermis comprised of columnar cells, and a single external opening at the base of the stigma (Figures $5 \mathrm{c}$ and $6 \mathrm{c}-\mathrm{d}, \mathrm{g}$ ). The inner epidermis of the ovary is comprised of secretory cells, forming the obturator (Figure 7f).

The ovule is anatrope (Figure 6a) and bitegumented; the external tegument is thicker and more extensive than the inner tegument, covering it and extending beyond it, restricted to the region of the micropyle (Figure 7d, g-h). In the region of the micropyle, cells of the two teguments and a layer of nucellus with elongated cells present phenolic compounds forming the epistase (Figure 7e, g-h). In the opposite position, it is possible to see the hypostasis formed by various layers of cells with phenolic compounds (Figure $7 \mathrm{~d}, \mathrm{~g}$ ). The vascular bundle reaches the chalaza and then branches to form the pachychalaza (Figure $7 \mathrm{~g}$ ). The nucellus has a single layer of cells, terminating at the middle region of the embryo sac (Figure 7e).

\section{Discussion}

According to Wright and Van Schaik (1994), in tropical rainforests, water is not a limiting factor and the more prolific production of flowers is related to the greater sunlight in periods of lower rainfall and higher temperatures, which was not observed in the collection sites of in individuals of $S$. inajai, que floresceram a fact that may be related to the size of the tree species in that there is no light restriction, since they occupy the upper strata of the forest canopy. The same is observed with Mauritia 
flexuosa L.f., which flowers from February to August (Storti, 1993).

Henderson and Scariot (1993) describe, for individuals of $S$. inajai, inflorescencis with up to 35 rachillae. In the present work, the number of rachillae varies from 18 to 36 .

The arrangement of the flowers in triads characterizes the subfamily Arecoideae (Dransfield et al., 2008). This arrangement is considered a possible synamorphy for Arecoideae, lost in some taxa, such as Chamaedorea, a genus of dioic palms with solitary flowers, or in acervulae (Askgaard et al., 2008; Dransfield et al., 2008). Asmussen et al. (2006) suggest that the origin of the triad arrangement comes from two basal staminate and one distal pistillate flower. The anatomical evidence suggests that the solitary flowers derive from a unit of the original acervulum that has suffered abortion of the distal flowers (Dransfield et al., 2008). In S. inajai, besides the standard triad arrangement, entirely male inflorescences were also observed. Bacelar-Lima et al. (2006) observed only staminate flowers in the apical rachillae of four of the seven inflorescences of Astrocaryum aculeatum studied, which is a new finding for this species. Field research enabled other patterns to be observed, often new and unlike those already reported.

It is presumed that the unisexual flowers and sexual dimorphism represent derived conditions in palms (Moore and Uhl, 1982; Tomlinson, 1990; Adam et al., 2007). In $S$. inajai, the pistillodium and the staminoidal ring of the staminate and pistillate flowers, respectively are vestigial organs. Daher et al. (2010), studying the transition from bisexual to unisexual flowers in Phoenix dactylifera L., observed that the non-development of the residual organs is due to paralyzation of the cell activity, and not to cell death in the tissues of these organs.

Palms belonging to the Subfamily Arecoideae present inflorescences surrounded by a penduncular bract that protects the flower during part of its development (Tomlinson, 1990; Dransfield et al., 2008). The opening of the peduncular bract in $S$. inajai occurred within 50 to 60 days, after its emergence. A study with Astrocaryum aculeatum (Barcelar-Lima et al., 2006) observed that the opening of the peduncular bract can take 30 to 45 days after its emergence. For Mauritia flexuosa this period was approximately 60 days (Storti, 1993).

The presence of protandria, in the species studied, makes self-pollination impossible. The same characteristic was observed in Euterpe precatoria (Kuchmeister et al., 1997), Elaeis guineenses (Adam et al., 2007), Normanbya normanbyi (W.Hill) L.H. Bailey (Inkrot et al., 2007) and Licuala peltata Roxb. ex Buch.-Ham. (Stauffer et al., 2009). In Geonoma irena Borchs. and Geonoma cuneata var. sodiroi (Dammer ex Burret) A.J. Hend., there was overlapping of the male and female phases (Borchsenius, 1996).

In both staminate and pistillate flowers, the sepals and petals are richly vascularized, forming an almost continuous layer of vascular bundles in the mesophyll, which corroborates with Stauffer et al. (2004), who ob- served the same characteristic in Pelagodoxa and Sommieria.

The morphological appearance of the stamens of $S$. inajai, (six in number, with wider filaments at the base; anthers with asymmetrical tips, dorsifixed, and longitudinal in dehiscence, introrse) are confirmed with the observations in species of the genera Pelagodoxa and Sommieria (Stauffer et al., 2004), Astrocaryum (Bacelar-Lima et al., 2006), Licuala (Stauffer et al., 2009).

According to Dransfield et al. (2008) the pollen grain with finely reticulated surface (Figure 2d) is characteristic of the genus Syagrus. The same appearance was also observed in the palms studied by Barth and Barbosa (1971). Perera et al. (2010) observed a protein reserve in the microspore of Cocos nucifera, and the same was observed in S. inajai.

Syagrus inajai presented a secretory epidermis, in the septa (septal nectary), similar to that observed in Euterpe precatoria, in the Subtribe Geonomeae, Asterogyne, Pelagodoxa, Sommieria and in Cocos nucifera and Licuala peltata, which the authors termed septal nectary (Kuchmeister et al., 1997; Stauffer et al., 2002; Stauffer and Endress, 2003; Stauffer et al., 2003; Stauffer et al., 2004; Guevara and Jáuregui, 2008; Stauffer et al., 2009). The septal nectary is formed by the incomplete union of the carpel flanks (Weberling, 1992; Stauffer and Endress, 2003; Stauffer et al., 2004; Rudall et al., 2011). Uhl and Moore (1977) mention that the septal nectaries have a secretory epidermis, and interact with pollinators. Based on the morphoanatomical characteristics of the septal nectaries, possible visitors are bees and small Coleoptera. Thum and Costa (1998) report that bees are the main floral visitors of Syagrus romazoffiana (Cham.) Glassm. Kuchmeister et al. (1997) observed, in Euterpe precatoria, the presence of nectar in these septal canals, possibly functioning as an attraction for visitation by these insects, and report bees and beetles as possible pollinators.

The anatropous ovule, a characteristic not previously reported for the genus Syagrus had already been reported for other genera of the Tribe Cocoseae, with Attalea and Cocos (Uhl and Moore, 1971; Guevara and Jauregui, 2008). However, Bactris sp and Elaeis oleifera (Kunth) Cortes belong to the same tribe and have an orthotropous ovule. The same occurs with Butia capitata, which presents a third type of ovule; hemitropous. These species were described by Uhl and Moore (1971), in that period, as belonging to the subfamily Cocosoideae (Potztal, 1964), but today they are included in the Tribe Cocoseae and Attalea, Butia and Syagrus the Subtribe Attaleinae (Dransfield et al., 2008). In other words, it is possible to see that in the tribe Cocoseae and the subtribe Attaleinae, there are different types of ovules, which means this characteristic cannot be used to distinguish these groups.

The description of the ovule of $S$. inajai provides new information, complementing previous research carried out with the genus (Henderson, 1995; Henderson et al., 1995, Dransfield et al., 2008). 
The presence of pachychalaza in the ovule of $S$. inajai is a fact not previously reported for the genus. According to Werker (1997), the pachychalaza is formed from the enlargement of the chalaza, forming a large portion of the seed involucrum. The hypostasis is located above the vascularization of the pachychalaza, and is comprised of cells containing a phenolic compound, which form a hood around the embryo sac, protecting the ovule from the action of pathogens due to its antimicrobial and antiviral properties (Swain, 1979; Von Teichman and Van Wyk, 1994).

The occurrence of pachychalaza and hypostasis is generally associated with bitegumented. Crassinucelate ovules, with large embryos, absence of endosperm or nuclear endosperm, arboreal habit, and tropical habitat (Von Teichman \& Van Wyk, 1991; Carmello-Guerreiro and Sartori Paoli 2000). These characteristics corroborate with those observed in $S$. inajai, but to characterize the nucellus, study of the development of the ovule is needed, and to characterize the endosperm, study of the development of the seed, a field as yet unexplored.

The morphoanatomical characteristics of the gynoecium, such as the pachychalazal ovule, and internal tegument restricted to the micropyle region, indicates which tissues are present in the fruit and seed of S. inajai.

\section{Acknowledgments}

The National Council for Scientific and Technological Development (CNPq), for the doctorate scholarship granted to the first author.

\section{References}

ADAM, H., JOUANNIC, S., MORCILLO, F., VERDEIL, JL., DUVAL, Y. and TREGEAR, JW., 2007. Determination of Flower Structure in Elaeis guineensis: Do Palms use the Same Homeotic Genes as Other Species? Annals of Botany, vol. 100, p. 1-12.

ASKGAARD, A., STAUFFER, FW., HODEL, DR. and BARFOD, A., 2008. Floral structure in the neotropical palm genus Chamaedorea (Arecoideae, Arecaceae). Anales del Jardín Botánico de Madrid, vol. 65, p. 197210.

ASMUSSEN, CB., DRANSFIELD, J., DEICKMANN, V., BARFOD, AS., PINTAUD, JC. and BAKER, WJ., 2006. A new subfamily classification of the palm family (Arecaceae): evidence from plastid DNA phylogeny. Botanical Journal of the Linnean Society, vol. 151, p. 15-38.

BACELAR-LIMA, CG., MENDONÇA, MS. and BARBOSA, TCS., 2006. Morfologia Floral de uma população de Tucumã, Astrocaryum aculeatum G. Mey. (Arecaceae) na Amazônia. Acta Amazônica, vol. 36, p. 407-412.

BARTH, OM. and BARBOSA, AF., 1971. Catálogo sistemático dos pólens das plantas arbóreas do Brasil Meridional XIIPalmae. Memórias do Instituto Oswaldo Cruz, vol. 69, no. 3, p. 425-433.

BORCHSENIUS, F., 1997. Flowering biology of Geonoma irena and G. cuneata var. sodiroi (Arecaceae). Plant Systematics Evolution, vol. 208, p. 187-196.

BRUNDETT, MC., KENDRICK, B. and PETERSON, CA., 1991. Efficient lipid staining in plant material with Sudan Red 7B or Fluoral Yellow 088 in polyethylene glycol- glycerol. Biotechnic \& Histochemistry, vol. 66, p. 111116.

BUKATSCH, F., 1972. Bemerkungen zur Doppelfarbung Astrablau-Safranin. Mikrokosmos vol. 61, 255 p.

CARMELLO-GUERREIRO, SM. and PAOLI, AAS., 2000. Estrutura do pericarpo e da semente de Astronium glaveolens Jacq. (Anacardiaceae) com notas anatômicas. Revista Brasileira de Botânica, vol. 23, no. 1, p. 87- 96.

DAHER, A., ADAM, H., CHABRILLANGE, N., COLLIN, M., MOHAMED, N., TREGEAR, JW. and ABERLENC-BERTOSSI, F., 2010. Cell cycle arrest characterizes the transition from a bisexual floral bud to a unisexual flower in Phoenix dactylifera. Annals of Botany, p. 1-12.

DRANSFIELD, J., UHL, NW., ASMUSSEN, CBA., BAKER, WJ., HARLEY, MM. and LEWIS, CE., 2008. Genera Palmarum - The Evolution and Classification of Palms. Richmond, UK: Kew Publishing.

DOP, P. and GAUTIÉ, A., 1928. Manuel technique. 2 ed. Paris: J. Lamane.

GUEVARA, LO. and JÁUREGUI, D., 2008. Anatomía floral de Cocos nucifera L. (Arecaceae, Arecoideae). Acta Botánica Venezuelica, vol. 31, no. 1, p. 35-48.

HENDERSON, A. and SCARIOT, AA., 1993. Flórula da Reserva Ducke, I: Palmae (ARECACEAE). Acta Amazônica, vol. 23 , no. 4 , p. 349-369.

HENDERSON, A., GALEANO, G. and BERNAL, R., 1995. Field Guide to the Palms of the Americas. Princenton: University Press, Princenton.

HENDERSON, A., 1995. The palms of the Amazon. New York: Oxford University Press.

INKROT, D., SATTLER, D., GEYER, C. and MORAWETZ, W., 2007. Flowering and fruiting phenology of Normanbya normanbyi (W. Hill) L.H. Bailey (Arecaceae), a palm endemic to the lowland tropical rainforest of north-eastern Australia. Austral Ecology, vol. 32, p. 21-28.

JENSEN, WA., 1962. Botanical Histochemistry: Principles and Practice. San Francisco: W. H. Freeman \& Co., 408 p.

JOHANSEN, DA., 1940. Plant microtechnique. New York: McGraw-Hill, $523 \mathrm{p}$.

KÖPPEN, W., 1931. Climatologia. Buenos Aires: Fondo de Cultura Econômica.

KORNERUP, A. and WANSCHER, JH., 1961. Taschenlexikon der Farben. Zürich: Musterschmidt. 242 p.

KRAUS, JE. and ARDUIN, M., 1997. Manual básico de métodos em morfologia vegetal. Rio de Janeiro: Edur.

KUCHMEISTER, H., SILBERBAUER-GOTTSBERGER, I. and GOTTSBERGER, G., 1997. Flowering, pollination, nectar standing crop, and nectaries of Euterpe precatoria (Arecaceae), an Amazonian rain forest palm. Plant Systematics and Evolution, vol. 206, p. 71-97.

LILLIE, RD., 1965. Histopathologic technic and practical histochemistry. 3 ed. New York: McGraw Hill.

MEEROW, AW., 1991. Palm seed germination. Bulletin, 274. Florida: Cooperative Extension Service, 10p.

MOORE, JR. HE. and UHL, NW., 1982. Major trends of evolution in palms. The Botanical Review, vol. 48, p. 1-69.

O'BRIEN, TP., FEDER, N. and MCCULLY, ME., 1964. Polychromatic staining of plant cell walls by toluidine blue. $O$ Protoplasma, vol. 59, p. 368-373.

O'BRIEN, TP. and MCCULLY, ME., 1981. The study of structure principles and selected methods. Melbourne: Termarcarphi. $280 \mathrm{p}$.

PERERA, PIP., HOCHER, V., WEERAKOON, LK., YAKANDAWALA, DMD., FERNANDO, SC. and VERDEIL, JL., 2010. Early inflorescence and floral development in 
Cocos nucifera L. (Arecaceae). South African Journal of Botany, vol. 76, p. 482-492.

PIVETTA, KFL., SARZI, I., ESTELITTAS, M. and BECKMANN-AVALCANTE, MZ., 2008. Tamanho do diásporo, substrato e temperatura na germinação de sementes de Archontophoenix cunninghamii (Arecaceae). Revista de Biologia e Ciências da Terra, vol. 8, p. 126-134.

POTZTAL, E., 1964. Reihe Principes (Palmales, Arecales). In MELCHIOR, H., (Ed). Engler's Syllabus der Pflanzenfamilien. Berlin: Gebruder Borntraeger. vol. 2, p. 579-588.

RUDALL, PJ., RYDER, RA. and BAKER, WJ., 2011. Comparative gynoecium structure and multiple origins of apocarpy in Coryphoid palms (Arecaceae). International Journal of Plant Sciences, vol. 172, no. 5, p. 674-690.

SALM, R., 2005. Arborescent Palm Seed Morphology and Seedling Distribution. Brazilian Journal of Biology, vol. 65 no. 4, p. $711-716$

STAUFFER, FW., RUTISHAUSER, R. and ENDRESS, PK., 2002. Morphology and development of female flowers in Geonoma interrupta (ARECACEAE). American Journal of Botany, vol. 89, p. 220-229.

STAUFFER, FW and P.K. ENDRESS, PK., 2003. Comparative morphology of female flowers and systematics in Geonomeae (Arecaceae). Plant Systematics and Evolution, vol. 242, p. 171-203.

STAUFFER, FW., ASMUSSEN, CB., HENDERSON, A. and ENDRESS, PK., 2003. A revision of Asterogyne (Arecaceae:Arecoideae: Geonomeae). Brittonia, vol. 55, no. 4, p. 326-356.

STAUFFER, FW, BAKER, WJ., DRANSFIELD, J. and ENDRESS, PK., 2004. Comparative floral structure and systematics of Pelagodoxa and Sommieria (Arecaceae). Botanical Journal of the Linnean Society, vol. 146, p. 27-39.

STAUFFER, FW., BARFOD, A. and ENDRESS, PK., 2009. Floral structure in Licuala peltata (Arecaceae:
Coryphoideae) with special reference to the architecture of the unusual labyrinthine nectary. Botanical Journal of the Linnean Society, vol. 161, p. 66-77.

STORTI, EF., 1993. Biologia Floral de Mauritia flexuosa Lin.Fil., na região de Manaus, Am, Brasil. Acta Amazônica, vol. 23 , no. 4, p. 371-381.

SWAIN, T., 1979. Tannins and Lignins. In ROSENTHAL, GA. and JANSEN, DH. (eds.). Herbivores, their interaction with secondary plant metabolites. New York: Academic Press. p. 657-682.

TOMLINSON, PB., 1990. The Structural Biology of Palms. New York: Oxford University Press. 477 p.

THUM, AB. and COSTA, EC., 1998. Entomofauna visitante das inflorescencias de Syagrus romanzoffiana (Cham.) Glassm. (Palmae). Revista das Faculdades de Zootecnia Veterinária e Agronomia, vol. 5, no. 6, p. 43-47.

UHL, NW. and MOORE, HE., 1971. The Palm Gynoecium. American Journal of Botany, vol. 58, no. 10, p. 945-992.

-, 1977. Correlation of inflorescence, flower structure, and floral anatomy with pollination in some palms. Biotropica, vol. 9, p. 170-190.

VON TEICHMAN, I. and VAN WYK, AE., 1991. Trends in the evolution of dicotyledonous seeds based on character associations, with special reference to pachychalazy and recalcitrance. Botanical Journal of the Linnean Society, vol. 105, p. 211-237.

VON TEICHMAN, I. and VAN WYK, AE., 1994. The generic position of Protorhus namaquensis Sprague (Anacardiaceae) - evidence from fruit structure. Annals of Botany, vol. 73, p. 175-184.

WEBERLING, F., 1992. Morphology of flowers and inflorescences. London: Cambridge University Press.

WERKER, E., 1997. Seed anatomy. Berlin: Gebrüder Borntraeger. $424 \mathrm{p}$.

WRIGHT, SJ. and VAN SCHAIK, CP., 1994. Light and phenology of the tropical trees. The American Naturalist, vol. 143, no. 1, p. 193-199. 